\title{
THE $\left[{ }^{14} \mathrm{C}\right]$-AMINOPYRINE BREATH TEST A COMPARISON OF DIFFERENT FORMS OF ANALYSIS
}

\author{
D.A. HENRY, G. SHARPE, S. CHAPLAIN, S. CARTWRIGHT, G. KITCHINGMAN, \\ G.D. BELL \& M.J.S. LANGMAN
}

Department of Therapeutics, University of Nottingham, Nottingham NG5 1PB

1 Following ingestion of $\left[{ }^{14} \mathrm{C}\right]$-aminopyrine, breath ${ }^{14} \mathrm{CO}_{2}$ data were analysed from normal individuals, patients with hepatic disease, epileptics receiving anticonvulsant therapy and volunteers before and after treatment with glutethimide.

2 The 'standard' $2 \mathrm{~h}\left[{ }^{14} \mathrm{C}\right]$-aminopyrine breath test discriminated successfully between the main groups but failed to detect the change in microsomal enzyme function produced by glutethimide.

3 A 'modified' form of the $2 \mathrm{~h}$ breath test calculated from the area under the breath specific activity curve detected the increase in demethylation following glutethimide.

4 The breath elimination constant $(\mathrm{Kb})$ derived from the breath ${ }^{14} \mathrm{CO}_{2}$ disappearance curve was as sensitive as the 'modified' $2 \mathrm{~h}$ breath test and was simpler to compute.

5 Glutethimide $500 \mathrm{mg} /$ day for 14 days resulted in a $42 \%$ increase in the metabolic clearance of antipyrine and a $26 \%$ increase in demethylation of $\left[{ }^{14} \mathrm{C}\right]$-aminopyrine.

\section{Introduction}

Measurement of breath ${ }^{14} \mathrm{CO}_{2}$ produced by demethylation of ${ }^{14} \mathrm{C}$ labelled aminopyrine has been widely used as a convenient measure of hepatic microsomal enzyme function (Hepner \& Vesell, 1974; Bircher, Küpfer, Gikalov \& Preisig, 1976; Galizzi, Long, Billing \& Sherlock, 1978). Hepner \& Vesell (1975) have advocated single $(2 \mathrm{~h})$ breath sampling in their analyses expressing their results as percentage of administered ${ }^{14} \mathrm{C}$ dose excreted in the breath in $2 \mathrm{~h}$. Others have preferred to use repeated measurements to derive a constant from the slope of the ${ }^{14} \mathrm{CO}_{2}$ disappearance curve (Bircher et al., 1976), a figure which does not require that assumptions be made about endogenous $\mathrm{CO}_{2}$ production rates.

Both measures have been shown to be suitable indices of the clear changes in microsomal function which accompany diseases such as hepatic cirrhosis or cardiac failure, and therapy with potent inducing agents such as anticonvulsant drugs (Hepner, Vesell, Lipton, Harvey, Wilkinson \& Schenker, 1977; Hepner, Vesell \& Tantum, 1978). The metabolic sequence preceding the appearance of ${ }^{14} \mathrm{CO}_{2}$ in the breath is complex and the rate limiting step is unclear (Platzer, Galeazzi, Karlaganis \& Bircher, 1978). It is also unclear if the $2 \mathrm{~h}\left[{ }^{14} \mathrm{C}\right]$-aminopyrine breath test will detect minor changes in microsomal enzyme activity. We have examined the efficiency of different methods of conducting an aminopyrine breath test in discriminating between individuals with and without liver disease and in detecting the modest changes in hepatic enzyme activity following glutethimide treatment.

\section{Methods}

\section{Subjects}

Group 1-Patients with liver disease. Twenty individuals were studied, eight with histologically confirmed cirrhosis (four alcoholic, three cryptogenic and one primary biliary cirrhosis) and eight with gross hepatocellular disturbance (SGPT $>200 \mathrm{iu} / 1$ ), attributed to viral infection in five cases, alcohol abuse in two and isoniazid-induced damage in one instance. Of the remaining four patients, three had secondary hepatic tumour diagnosed on the basis of clinical findings, and positive hepatic scintiscan. One patient was suffering from congenital hepatic fibrosis.

Group 2-Epileptics receiving anticonvulsant drugs. Seven of these were receiving phenytoin $(2.9-6.0 \mathrm{mg} / \mathrm{kg})$ alone, and four phenytoin with phenobarbitone $(1.2-3.0 \mathrm{mg} / \mathrm{kg})$.

Group 3-Controls-These had no active disease. The group consisted of eight healthy members of the Department staff and twenty patients attending hospital for routine review 3 months after an uncomplicated myocardial infarction. No drugs were 
being taken at the time of study, no patient had evidence of cardiac failure and there was no clinical or biochemical evidence of liver disease.

The eight healthy departmental members who had acted as normal controls agreed to a study in which detailed analyses of breath ${ }^{14} \mathrm{CO}_{2}$ were performed before and after 14 days' treatment with glutethimide $500 \mathrm{mg}$ each night. In order to confirm and quantitate the degree of enzyme induction antipyrine clearance and urinary D-glucaric acid excretion was measured at the beginning and end of the study.

The study was approved by the hospital ethical committee and the procedures were explained to each participant.

\section{Procedures}

$\left[{ }^{14} \mathrm{C}\right]$-aminopyrine breath test. All studies were performed fasting. Modest physical activity within the confines of the department was allowed. The ${ }^{14} \mathrm{C}$ labelled aminopyrine was obtained from the Radiochemical Centre Amersham, and $2 \mu \mathrm{Ci}$ was administered dissolved in $50 \mathrm{ml}$ water. Subjects blew into a vial containing $2 \mathrm{ml}$ hyamine hydroxide as a $\mathrm{CO}_{2}$ trapping agent and thymolphthalein as an indicator, disappearance of the blue colour indicating the collection of $2 \mathrm{mmol}$ of exhaled $\mathrm{CO}_{2}$. Scintillation cocktail $(10 \mathrm{ml})$ was added and the ${ }^{14} \mathrm{C}$ activity was counted on a liquid scintillation counter (Nuclear Enterprises LSCI). The counting efficiency was determined before each study and was always in the range $72-75 \%$. Breath samples were routinely collected at hourly intervals for $6 \mathrm{~h}$ after ingestion of $\left[{ }^{14} \mathrm{C}\right]$-aminopyrine but additional samples were taken from the eight departmental volunteers at $5,10,15$, 20,30 and $45 \mathrm{~min}$ and at $1.5,2.5,3.5$ and $4.5 \mathrm{~h}$ before, and similarly after 14 days treatment with glutethimide. The breath ${ }^{14} \mathrm{CO}_{2}$ results were analysed in three ways:-

1. 'Standard' $2 \mathrm{~h}$ breath test. A figure for the $2 \mathrm{~h}$ breath test was calculated in every case as described by Hepner \& Vesell (1974). The mean 2 h count was expressed as the percentage of the administered dose of ${ }^{14} \mathrm{C}$ excreted as ${ }^{14} \mathrm{CO}_{2}$ in $2 \mathrm{~h}$. For the purpose of this calculation the endogenous $\mathrm{CO}_{2}$ production rate was assumed to be $9 \mathrm{mmol} \mathrm{h} \mathrm{h}^{-1} \mathrm{~kg}^{-1}$ (Winchell, Stahelin, Kusubov, Slanger, Fish, Pollycove \& Lawrence, 1970).

2. Breath elimination constant $(K b)$. $\mathrm{Kb}$ was calculated in every case from the slope of the least squares regression analysis of the decline in breath ${ }^{14} \mathrm{CO}_{2}$ activity beyond $2 \mathrm{~h}$. This was obtained from at least five breath samples collected between 2 and $6 \mathrm{~h}$ after ingestion of $\left[{ }^{14} \mathrm{C}\right]$-aminopyrine.

3. 'Modified' breath test. The frequent breath samples collected during the glutethimide study were plotted as disintegrations per minute $(\mathrm{d} / \mathrm{min}) / \mathrm{mmol} \mathrm{CO}_{2}$ against time (min) on $\mathrm{mm}^{2}$ arithmetic graph paper. The area under the resulting curve for each hourly period from $0-6 \mathrm{~h}$ was calculated from curve weights by one of us (DAH). The results were expressed as a percentage of the administered dose of ${ }^{14} \mathrm{C}$ excreted in the breath during each hourly interval from 0-6 h. For this calculation endogenous $\mathrm{CO}_{2}$ production was again assumed to be $9 \mathrm{mmol} \mathrm{h}-1 \mathrm{~kg}^{-1}$. The results obtained with these repeated measurements were then compared with a simplified method in which the breath ${ }^{14} \mathrm{CO}_{2}$ specific activity during each hour was assumed to be the mean of the simple readings obtained at the beginning and end of each hour for the six hours (Hepner \& Vesell, 1974).

\section{Antipyrine clearance (glutethimide study only)}

Antipyrine was administered orally in a dose of 15 $\mathrm{mg} / \mathrm{kg}$ to fasting volunteers before and after treatment with glutethimide. Blood was drawn at 3,6, 8,12 and $24 \mathrm{~h}$ and plasma antipyrine levels were measured spectrophotometrically by the method of Brodie, Axelrod, Soberman \& Levy (1949). The data were fitted to a least squares regression analysis and figures were obtained for antipyrine clearance from the formula;

$$
\mathrm{MCR}=\mathrm{Vd} \times \mathrm{Kel}
$$

where $\mathrm{MCR}=$ metabolic clearance rate, $\mathrm{Vd}=$ volume of distribution and $\mathrm{Kel}=$ elimination constant. Results were expressed as $\mathrm{ml} \mathrm{min}{ }^{-1} \mathrm{~kg}^{-1}$ body weight.

Urinary D-glucaric acid excretion (glutethimide study only)

Morning urine samples were obtained in a fasting state from the eight volunteers before and after treatment with glutethimide. D-glucaric acid was measured by the method of Simmons, Davis, Dordoni \& Williams (1974) and urinary creatinine values obtained from the autoanalyser in the hospital biochemistry department. Urinary D-glucaric acid excretion was expressed as $\mu \mathrm{mol} \mathrm{D}$-glucaric acid $/ \mathrm{g}$ creatinine.

\section{Results}

Values for the 'standard' $2 \mathrm{~h}\left[{ }^{14} \mathrm{C}\right]$-aminopyrine breath test were calculated in 59 instances and the results are given in Figure 1. Values (mean \pm 1 s.d.) for percentage dose excreted in $2 \mathrm{~h}$ were: epileptic group $14.9 \pm 2.2 \%$ and normals $9.9 \pm 1.9 \%$. This difference was statistically highly significant $(t=7.04, P<0.001$, Student's $t$-test). The results from the hepatic disease 


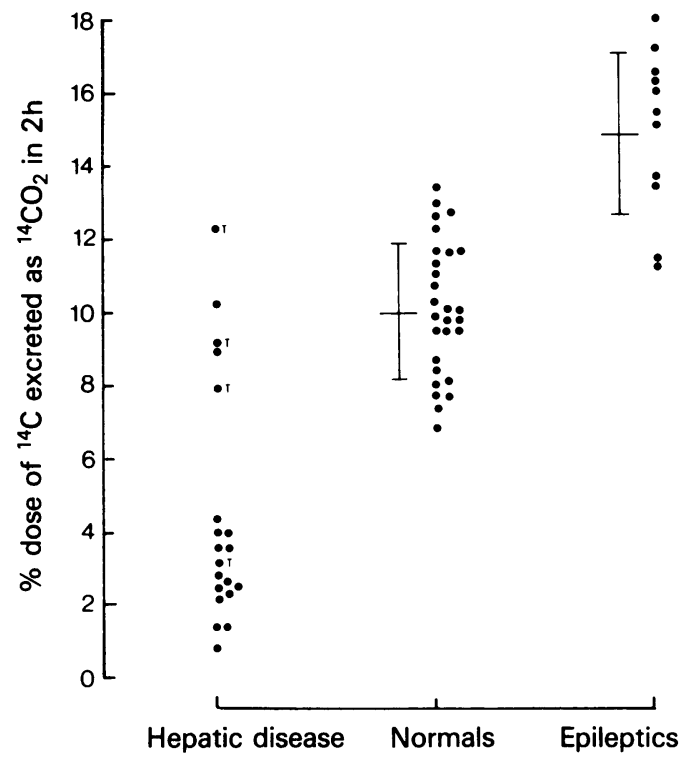

Figure 1 Results of the 'standard' $2 \mathrm{~h}\left[{ }^{14} \mathrm{C}\right]-$ aminopyrine breath test from three groups of individuals. Bars denote the mean $( \pm 1$ s.d.) values of the normal and epileptic groups. $\mathrm{T}$ indicates those individuals with hepatic disease for whom it was possible to calculate $\mathrm{Kb}$ (see text).

group were bimodally distributed (Figure 1). This precluded normal analysis. Five patients with hepatic disease had normal values for the 'standard' $2 \mathrm{~h}$ breath test. This group comprised three individuals with cirrhosis (two 'cryptogenic' and one alcoholic), one with primary biliary cirrhosis and one with hepatic fibrosis. The results from the remainder of the group fell outside two standard deviations of the mean value of the controls. No patient with hepatitis had a normal result. Because of delay in excretion of ${ }^{14} \mathrm{CO}_{2}$ (Figure 2) it was possible to calculate a $\mathrm{Kb}$ value from the ${ }^{14} \mathrm{CO}_{2}$ disappearance curve for only four of the hepatic patients. Three had been previously identified amongst the five of the hepatic disease group with normal values for the 'standard' $2 \mathrm{~h}$ breath test. Their $\mathrm{Kb}$ values were $0.22,0.22,0.21$ and $0.14 \mathrm{~h}^{-1}$. All four results fall outside two standard deviations of the moan value of the control group (mean \pm 1 s.d. $\left.0.33 \pm 0.05 \mathrm{~h}^{-1}\right)$. The mean $( \pm 1$ s.d.) $\mathrm{Kb}$ value of the epileptic group was $0.46 \pm 0.06 \mathrm{~h}^{-1}$. The difference between this and the control value was highly significant ( $t=6.75, P<0.001$, Student's $t$-test), but did not provide better separation of the two groups than the 'standard' $2 \mathrm{~h}$ breath test. In each calculation a group of four epileptics had results which fell within two standard deviations of the mean of the control group. These two groups were mutually exclusive, as can be seen in Figure 3.

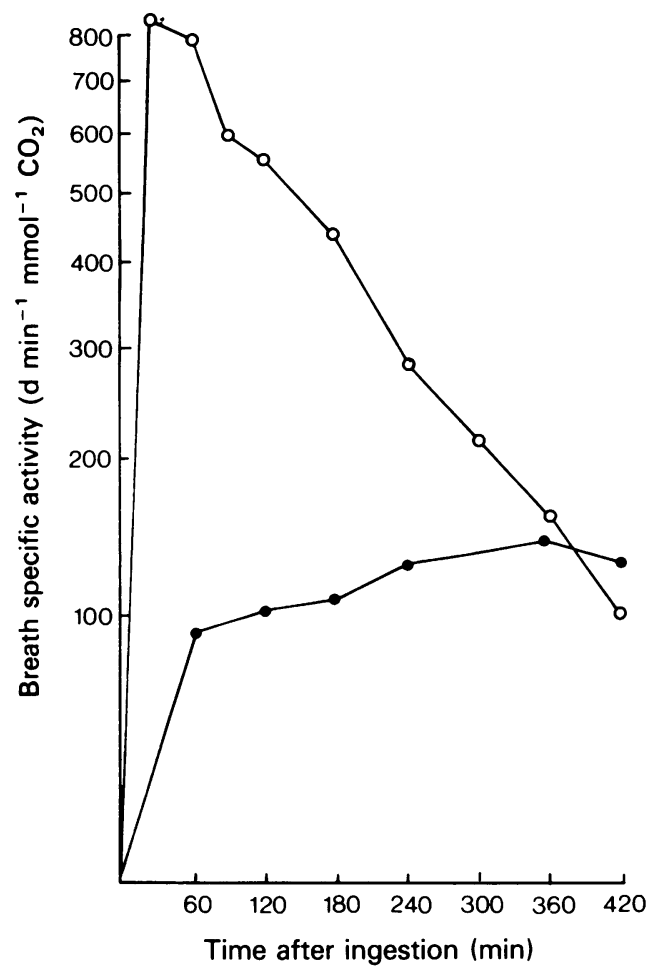

Figure 2 Breath ${ }^{14} \mathrm{CO}_{2}$ specific activity following ingestion of $2 \mu \mathrm{Ci}\left[{ }^{14} \mathrm{C}\right]$-aminopyrine. $(\mathrm{O})$ pattern of excretion in a normal individual, $(\mathcal{O})$ delayed excretion with 'plateau' effect in a patient with cryptogenic cirrhosis.

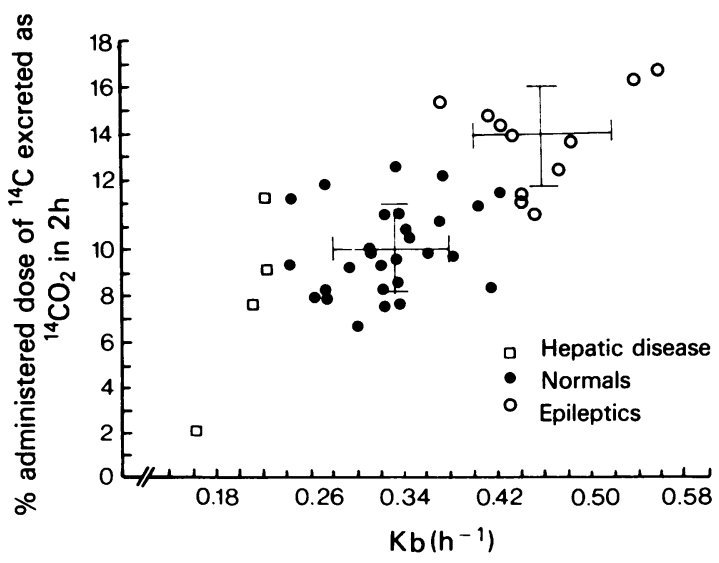

Figure 3 Scatter diagram of individual results for the 'standard' $2 \mathrm{~h}\left[{ }^{14} \mathrm{C}\right]$-aminopyrine breath test and the breath elimination constant $\mathrm{Kb}$. Bars denote mean values $( \pm 1$ s.d.) for both parameters. A group of four epileptics falls within the normal range for each estimate. The two groups are mutually exclusive. ( $\square$ ) hepatic disease, $(O)$ normals, $(O)$ epileptics. 


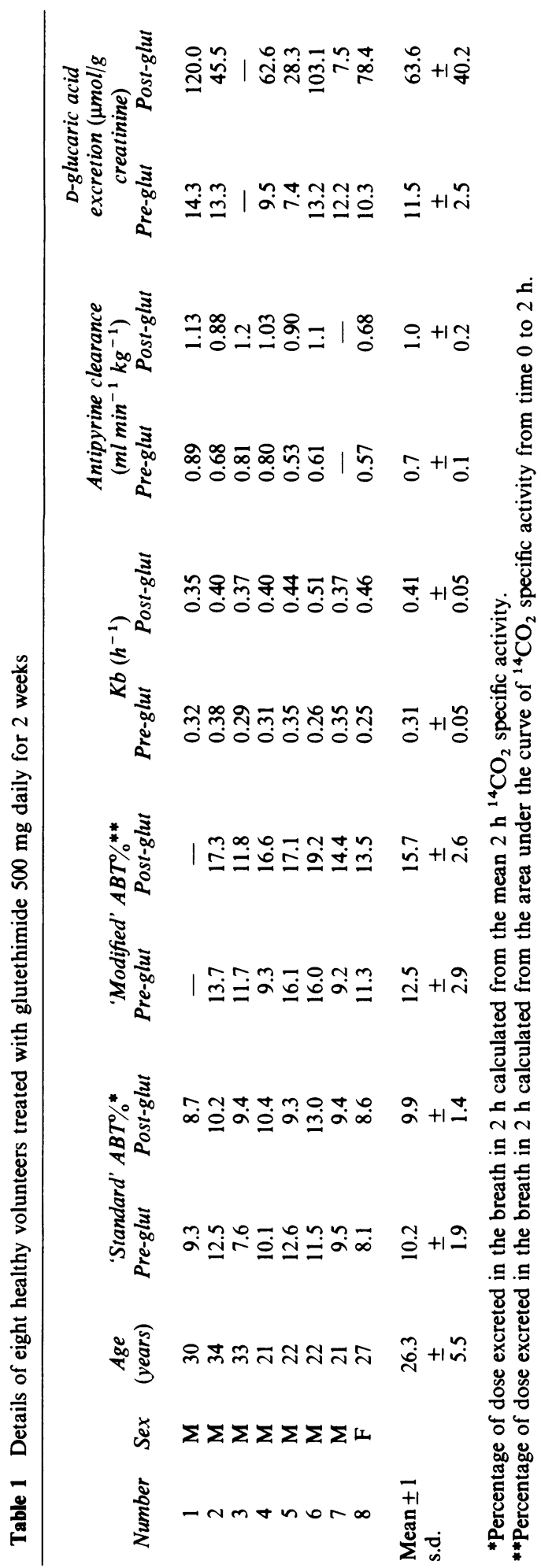

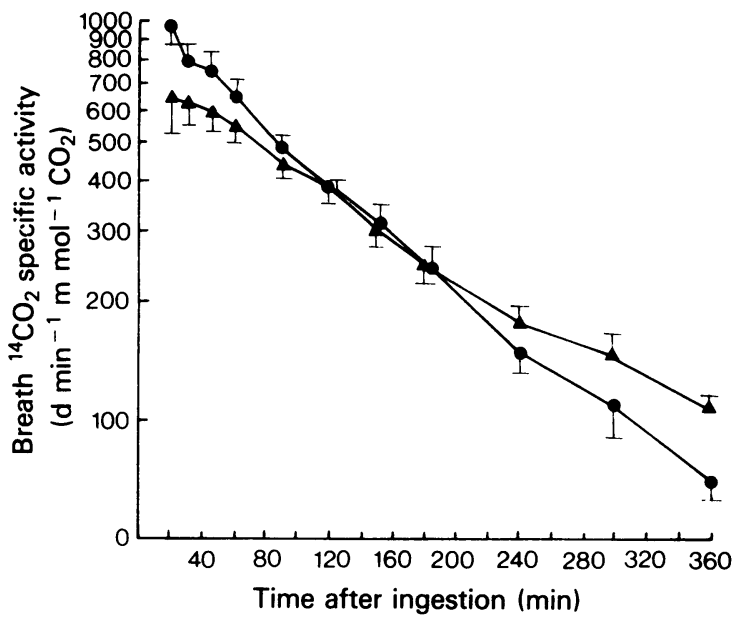

Figure 4 Breath ${ }^{14} \mathrm{CO}_{2}$ specific activities following ingestion of $\left[{ }^{14} \mathrm{C}\right]$-aminopyrine from seven healthy individuals before $(\Delta)$ and after $(O) 14$ days treatment with glutethimide. Points denote means ( \pm 1 s.e. mean).

\section{Glutethimide study}

The details of the eight normal individuals studied are given in Table 1. Following glutethimide treatment there were highly significant increases in values for the 'modified' $2 \mathrm{~h}$ breath test $(t=3.47, P<0.02$, paired $t$-test), the breath elimination constant $\mathrm{Kb}$ $(t=3.21, P<0.02$, paired $t$-test $)$, antipyrine clearance ( $t=5.86, P<0.005$, paired $t$-test) and D-glucaric acid excretion $(t=3.53, P<0.02$, paired $t$-test $)$. The 'standard' $2 \mathrm{~h}$ breath test value did not increase and failed to detect the clear changes in microsomal enzyme activity demonstrated by the other measures. The reason for this failure can be seen in Figure 4. Following ingestion of $\left[{ }^{14} \mathrm{C}\right]$-aminopyrine, peak breath ${ }^{14} \mathrm{CO}_{2}$ activity occurred at $20 \mathrm{~min}$ and thereafter exhibited a mono-exponential decline as far as $6 \mathrm{~h}$. As can be seen from the figure the mean $2 \mathrm{~h}$ breath ${ }^{14} \mathrm{CO}_{2}$ specific activity of the group was virtually unchanged by glutethimide. Values before $2 \mathrm{~h}$ were substantially higher, particularly following glutethimide and the slope of the disappearance curve was steepened by treatment. The clear increase in the area under the $2 \mathrm{~h}$ breath specific activity curve was reflected in a higher 'modified' $2 \mathrm{~h}$ breath test value in every case following glutethimide (Table 1). Figure 4 shows that readings after $3 \mathrm{~h}$ tended to be lower following glutethimide treatment, so that when breath test results from 3 to $6 \mathrm{~h}$ were taken into account the overall dose of ${ }^{14} \mathrm{C}$ excreted as ${ }^{14} \mathrm{CO}_{2}$ in $6 \mathrm{~h}$ increased only slightly. This figure (mean \pm 1 s.d.) calculated by the 'standard' method was $20.8 \pm 2.8 \%$ before and $21.3 \pm 3.4 \%$ after treatment. The same estimate derived from the area under the specific 


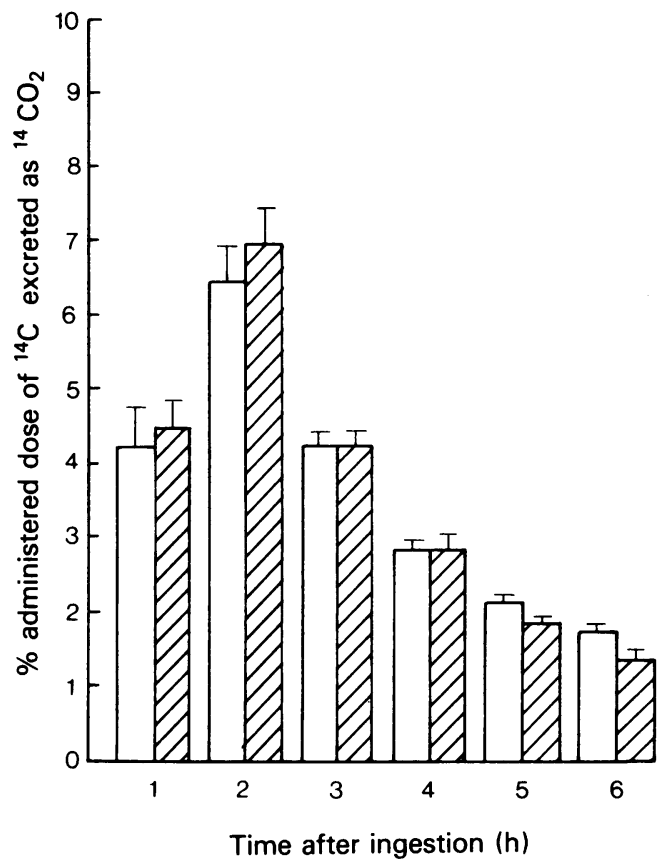

Figure 5 Percentage ${ }^{14} \mathrm{C}$ dose excreted as ${ }^{14} \mathrm{CO}_{2}$ in each hour after ingestion calculated by the 'standard' method. Figures refer to means $(+1$ s.e. mean) from seven volunteers before $(\square)$ and after $(\mathbb{G})$ treatment with glutethimide.

activity curve rose from $23.0 \pm 2.9 \%$ to $26.0 \pm 3.2 \%$. This difference failed to reach statistical significance $(t=2.36, P>0.05$, paired $t$-test). Figures 5 and 6 provide details of the proportion of administered ${ }^{14} \mathrm{C}$ dose eliminated in each hour after ingestion and the changes brought about by glutethimide.

Taking each of the five variables ('standard' $2 \mathrm{~h}$ breath test, 'modified' $2 \mathrm{~h}$ breath test, $\mathrm{Kb}$, antipyrine clearance, D-glucaric acid excretion) separately, correlations were attempted with each of the other four using individual values before and after glutethimide treatment. No statistically significant correlations were obtained either between the parameters themselves or the percentage increases brought about by glutethimide treatment.

\section{Discussion}

The $2 \mathrm{~h}^{14} \mathrm{C}$-aminopyrine breath test in its standard form is a convenient, safe, non-invasive investigation which uses tracer doses of drug and involves trapping of ${ }^{14} \mathrm{CO}_{2}$ by a simple method at a single point in time We have confirmed the value of this test clinically where there are large variations in hepatic microsomal enzyme function. Our data do not allow

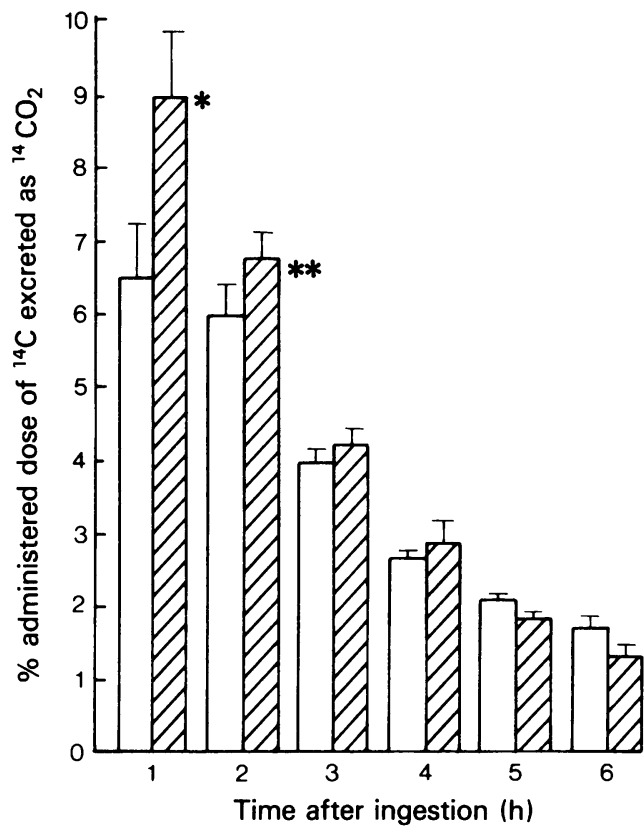

Figure 6 Percentage ${ }^{14} \mathrm{C}$ dose excreted as ${ }^{14} \mathrm{CO}_{2}$ in each hour after ingestion calculated from the area under the breath specific activity curve. Figures refer to means $(+1$ s.e. mean) from seven volunteers before $(\square)$ and after $(\mathbb{Z})$ treatment with glutethimide. ${ }^{*} P<0.05$, ** $P<0.02$.

inferences to be made about the ability of the test to differentiate various types of hepatic disease, but other workers have shown it to be a liver function test with reasonable discriminatory powers (Hepner \& Vesell, 1977; Galizzi et al., 1978). Our findings of normal $2 \mathrm{~h}$ breath test results in five patients with histologically demonstrated liver disease suggests that apparently normal results should be interpreted with caution. In three of these patients an elimination constant could be measured from the slope of the ${ }^{14} \mathrm{CO}_{2}$ disappearance curve, and in each case this was abnormal. The gross delay in appearance of ${ }^{14} \mathrm{CO}_{2}$ in the majority of the hepatic disease group made measurement of this constant impossible. Impaired metabolism is the likely explanation for this observation, but delayed absorption of aminopyrine in patients with liver disease has been suggested as a contributory factor (Pauwels, Geubel, Steels, Dive \& Beckers, 1978). It is likely that intravenous administration of $\left[{ }^{14} \mathrm{C}\right]$-aminopyrine, combined with collection of ${ }^{14} \mathrm{CO}_{2}$ up to or beyond $12 \mathrm{~h}$ would overcome this problem, but these measures render the test more cumbersome and invasive. Although the profile of delayed excretion of ${ }^{14} \mathrm{CO}_{2}$ with a plateau effect makes conventional analysis difficult, it is in itself of diagnostic value as we did not observe this pattern in 
any individual without liver disease.

By comparing normal individuals with subjects receiving chronic anticonvulsant therapy we have shown the 'standard' $2 \mathrm{~h}$ breath test to be as sensitive as the breath elimination constant in reflecting the major differences in microsomal enzyme activity between the two groups. The failure of the 'standard' $2 \mathrm{~h}$ breath test to change when normal individuals were treated with glutethimide was surprising, particularly as there were highly significant increases in antipyrine clearance and D-glucaric acid excretion. A delay in absorption of ${ }^{14} \mathrm{C}$ aminopyrine following glutethimide therapy seems an unlikely explanation as the time of peak breath ${ }^{14} \mathrm{CO}_{2}$ specific activity was unchanged by treatment. In our opinion this apparent lack of sensitivity of the standard test raises serious doubts about the wisdom of counting a single breath sample and assuming that the result represents a valid estimate of the mean breath ${ }^{14} \mathrm{CO}_{2}$ specific activity during the previous $2 \mathrm{~h}$. Frequent ${ }^{14} \mathrm{CO}_{2}$ sampling in the early stages of the test and measurement of the area under the breath specific activity curve allowed a more precise estimate of the percentage of the ${ }^{14} \mathrm{C}$ dose excreted as ${ }^{14} \mathrm{CO}_{2}$ in each hour. This measure and the breath elimination constant changed significantly following glutethimide. The standard method of analysis underestimates the proportion of ${ }^{14} \mathrm{C}$ eliminated as ${ }^{14} \mathrm{CO}_{2}$. The absorption and metabolism of aminopyrine are rapid and changes in the rate of demethylation are most readily demonstrated within the first $2 \mathrm{~h}$. Glutethimide in the dose administered increased the demethylation of aminopyrine by approximately $26 \%$ during the first two hours and estimates based on single breath ${ }^{14} \mathrm{CO}_{2}$ samples collected at or beyond this time failed to disclose this change.

When breath ${ }^{14} \mathrm{CO}_{2}$ data are used to obtain measures of percentage of administered dose of ${ }^{14} \mathrm{C}$ excreted in unit time, it is necessary to incorporate some estimate of endogenous $\mathrm{CO}_{2}$ production. The widely used figure of $9 \mathrm{mmol} \mathrm{h}^{-1} \mathrm{~kg}^{-1}$ for a resting

\section{References}

BIRCHER, J., KÜPFER, A., GIKALOV, I. \& PREISIG, R. (1976). Aminopyrine demethylation measured by breath analysis in cirrhosis. Clin. Pharmac. Ther., 20, 484-492.

BRODIE, B.B., AXELROD, J., SOBERMAN, R. \& LEVY, B.B. (1949). The estimation of antipyrine in biological materials. J. biol. Chem., 179, 25-29.

GALIZZI, J., LONG, R.G., BILLING, B.H. \& SHERLOCK, S. (1978). Assessment of the $\left[{ }^{14} \mathrm{C}\right]$-aminopyrine breath test in liver disease. Gut, 19, 40-45.

HEPNER, G.W. \& VESELL, E.S. (1974). Assessment of aminopyrine metabolism in man by breath analysis after oral administration of $\left[{ }^{14} \mathrm{C}\right]$-aminopyrine. $N$. Engl. J. Med., 291, 1384-1387.

HEPNER, G.W. \& VESELL, E.S. (1975). Quantitative assessment of hepatic function by breath analysis after healthy adult has been criticised on the grounds that changes in physical activity or calorific intake alter this rate and may affect the accuracy of results (Winchell et al., 1970; King \& Toskes, 1978). The effects of disease on this figure are unknown.

Our study of healthy individuals taking glutethimide was performed under controlled conditions with paired observations, so our measures of the change brought about by glutethimide should be unaffected by diet or other factors. Measurement of the breath elimination constant has the advantage that the only assumption made is in respect of the constancy of $\mathrm{CO}_{2}$ production by the individual during the period of study. This allows comparison of patients whose production rates may be different. Previous work has shown that the breath elimination constant correlates best with the metabolic clearance of unlabelled aminopyrine (Bircher et al., 1976). These facts plus the need we have demonstrated to perform frequent sampling in the early stages of the test and measure the area under the breath specific activity curve in order to increase the sensitivity of the $2 \mathrm{~h}$ breath test suggest that the breath elimination constant should be routinely measured when analysing ${ }^{14} \mathrm{CO}_{2}$ data.

Glutethimide treatment for 3 weeks has recently been shown to increase clearance of antipyrine by $55 \%$ (Jackson, Homeida \& Roberts, 1978). Our finding of a $42 \%$ increase after two weeks' treatment is consistent with this figure, and confirms earlier reports that glutethimide is a moderately active hepatic enzyme inducing agent (Jaroslinski, Browne \& Possley, 1972). By breath testing and measuring the area under the elimination curve we have demonstrated a $26 \%$ increase in the demethylation of aminopyrine within the first $2 \mathrm{~h}$ of administration and a $31 \%$ increase in the breath elimination constant measured over $6 \mathrm{~h}$. Taken together these findings suggest that breath testing is a useful simple non-invasive technique for assessing drug metabolism in man. oral administration of $\left[{ }^{14} \mathrm{C}\right]$-aminopyrine. Ann. int. Med., 83, 632-638.

HEPNER, G.W. \& VESELL, E.S. (1977). Aminopyrine metabolism in the presence of hyperbilirubinaemia due to cholestasis or hepatocellular disease. Clin. Pharmac. Ther., 21, 620-626.

HEPNER, G.W., VESELL, E.S., LIPTON, A., HARVEY, H.A., WILKINSON, G.R. \& SCHENKER, S. (1977). Disposition of aminopyrine, antipyrine, diazepam and indocyanine green in patients with liver disease or an anticonvulsant drug therapy: diazepam breath test and correlations in drug elimination. J. lab. clin. Med., 90, 440-456.

HEPNER, G.W., VESELL, E.S. \& TANTUM, K.R. (1978). Reduced drug elimination in congestive cardiac failure. Am. J. Med., 65, 271-276. 
JACKSON, L., HOMEIDA, M. \& ROBERTS, C.J.C. (1978). The features of hepatic enzyme induction with glutethimide in man. Br. J. clin. Pharmac., 6, 525-528.

JAROSLINSKI, J., BROWNE, R. \& POSSLEY, L. (1972). Effect of subacute administration of methaqualone, phenobarbital and glutethimide on plasma levels of dihydroxy coumarin. Arch. int. Pharmacodyn., 195, 185-191.

KING, C. \& TOSKES, P. (1978). A caveat-endogenous $\mathrm{CO}_{2}$ production increases during non-fasting carbon isotope breath tests. Proceedings of the VIth World Congress of Gastroenterology, Madrid, June 1978.

PAUWELS, P., GEUBEL, A.P., STEELS, M., DIVE, C. \& BECKERS, C. (1978). Breath analysis after intravenous administration of $\left[{ }^{14} \mathrm{C}\right]$-aminopyrine in man: a new promising liver function test. Proceedings of the VIth
World Congress of Gastroenterology, Madrid, June 1978. PLATZER, R., GALEAZZI, R.L., KARLAGANIS, G. \& BIRCHER, J. (1978). Rate of drug metabolism in man measured by ${ }^{14} \mathrm{CO}_{2}$ breath analysis. Eur. J. clin. Pharmac., 14, 293-299.

SIMMONS, C.J., DAVIS, M., DORDONI, B. \& WILLIAMS, R. (1974). Urinary D-glucaric acid assay by an improved enzymatic procedure. Clin. Chim. Acta. 51, 47-51.

WINCHELL, H.S., STAHELIN, H., KUSUBOV, N., SLANGER, B., FISH, M., POLLYCOVE, M. \& LAWRENCE, J.H. (1970). Kinetics of $\mathrm{CO}_{2}-\mathrm{HCO}_{3}{ }^{-}$in normal adult males. J. nucl. Med., 12, 711-715.

(Received February 19, 1979) 